\title{
Problémy a aspekty pojmu maska: Pokus o definici a vymezení
}

\author{
Vít Erban \\ Do redakce doručeno 9. listopadu 2016; k publikaci přijato 9. června 2017
}

Katedra filosofie a religionistiky, Teologická fakulta Jihočeské univerzity v Českých Budějovicích, Kněžská 8, České Budějovice

\section{PROBLEMS AND ASPECTS OF THE TERM „MASK“: AN ATTEMPT OF DEFINITION AND SPECIFICATION}

\begin{abstract}
Anthropology, ethnology and ethnography pays little attention to the question of what is a mask and how to define and specify it. Therefore, this term is used inconsistently or ambiguously. But if there is no consensus on what could be considered as a masks and if the question isn't asked and questioned the effort to arrive at general conclusions about the origin, meaning and function of the mask is difficult. Especially in comparative studies that try to grab a mask in an interdisciplinary, multigenre or intercultural context, the use of the term should be based on a steady terminology. This article aims to offer a precise definition of the mask, which would include all its functionally-meaning types. Masks are embedded in relativity, paradox and ambivalence and therefore can not have completely solid and clearly definable status, therefore the definition presented offers only certain factors that should be taken into account, but does not establish clear boundaries and firm categories. The main objective of the paper is to stimulate debate.
\end{abstract}

KEY WORDS mask; identity; performance, carnival; Czech folk culture

ABSTRAKT V odborné literatuře je věnována malá pozornost problému, co je vlastně maska a jak ji definovat a vymezit. Proto se tento pojem používá nejednotně a nejednoznačně. Pokud však není shoda v tom, co lze, nebo naopak nelze pokládat za masku a pokud tato otázka není ani problematizována, snaha dobrat se obecných závěrů o původu, významu a funkcích masky je obtížná. Především ve studiích zaměřených komparativně, které se pokouší uchopit masku v mezioborovém, multižánrovém nebo mezikulturním kontextu, je třeba vycházet z určité ustálené terminologie. Cílem této stati je nabídnout co možná nejpřesnější vymezení masky, které by zahrnovalo všechny její funkčně-významové typy. Masky svým zakotvením v relativitě, paradoxu a ambivalenci nemohou mít zcela pevný a jasně definovatelný status, proto předložená definice nabízí pouze určité faktory, které je třeba vzít v úvahu, neumožňuje však stanovit jasné hranice a pevné kategorie. Svým pracovním účelem chce především podnítit diskuzi.

KLÍČOVÁ SLOVA maska; identita; představení; masopust; česká lidová kultura

\section{ÚVOD}

Nejrůznější aspekty sebeprezentace, výrazu a práce s identitou jsou jedním ze základních projevů veškeré živé přírody (srov. Caillois 1968; Portmann 1997; Komárek 2016), ale také neodmyslitelnou a trvalou součástí lidské kultury (srov. Caillois 1998; Komárek 2008). V antropologické (etnografické i etnologické), ale také muzeologické, teatrologické a uměnovědní literatuře věnující se tématu masek, maškar, maskování, ma- sopustů, karnevalů, slavností a širších vztahů mezi divadlem, hrou a rituálem je jen málokdy věnována bližší pozornost zdánlivě nepodstatnému terminologickému problému, co je vlastně maska $\mathrm{v}$ rozmanitosti svých funkčně-významových variant a jak ji v kontextu jiných estetických, symbolických či utilitárních aspektů lidského zacházení s identitou rozpoznat a vymezit. Pozoruhodnou výjimkou je zejména francouzský religionista Henry Pernet, který hned úvodem své studie poznamenává, že jakkoli můžeme mít dojem, že intuitivně či 
na základě zkušenosti víme a bezpečně poznáme, co je maska, je co možná nejpřesnější definice masky důležitá a nenahraditelná, protože jen s její pomocí budeme schopni rozpoznat šíři variant maskování, aniž bychom tento pojem natolik rozšiřiili a vyprázdnili, že se stane nepoužitelným a jeho podstata se spíš rozplyne, než aby se vyjevila (Pernet 2006, 10-11). Někteří autoři skutečně vycházejí z předpokladu, že artefakt masky není nutné ani možné jasně definovat, přesto jej však snadno rozpoznáme i ve zcela odlišném kulturním kontextu (např. Edson 2005, 218), jiní podávají vlastní definici masky bez kritické konfrontace $s$ definicemi jiných autorů (např. Ebelová 2012,9 ), většina autorů se však této problematice vyhýbá. Přitom na zásadní metodologické překážky zpochybňující toto nekriticky intuitivní pojetí už před půlstoletím výstižně poukázala americká antropoložka Elisabeth J. Tooker: „Asi první, co nám přijde na mysl, je význam masky jako zakrytí tváre. Avšak, měly by být $k$ těmto plným maskám přrirazeny také masky poloviční či částečné? A pokud ano, co potom závoje, malba na tvár a tetování či hmotné objekty nebo ozdoby hlavy, které nezakrývají obličej? Existují masky, které se používají za života, ale také masky posmrtné, maskarony a miniatury masek príliš malé na to, aby mohly sloužit k zakrytí obličeje, a velké vyřezávané sochy, jež jsou také označovány jako masky. Navíc ne všechny masky mají posvátné konotace. I v naší společnosti už jen částečný seznam takovýchto sekulárních a utilitárních masek zahrnuje baseballové masky, šermírské masky, svářečské, potápěčské, chirurgické, zločinecké, plynové, anestetické, okrasné masky či masky divadelní použivané v řeckých či japonských divadelních hrách" (Tooker 1983, 12).

\section{POJEM MASKA A MAŠKARA V SOUČASNÉ ETNOGRAFII}

Právě na takové nejasnosti dodnes narážíme v celé řadě humanitních oborů včetně domácího národopisu. Tak např́klad obřadně tancující „turci“ či „mládenci“ tzv. červené masopustní maškary na Hlinecku jsou v literatuře označováni jako typické prríklady tradičních masek (Hrníčko 1988, 149-151; Vojancová 2014, 15), zatímco v př́padě tanečníků doudlebské tzv. mládenecké či růžičkové masopustní koledy je za nositele masek (maškary) považován pouze jejich méně obřadný doprovod (např. Staňková - Baran 1998, 14; Kratochvíl - Tyllner 2007, 13; Stavělová 2008, 21), přestože funkce, chování, ale i kostým a atributy těchto obřadních tanečníků jsou velmi podobné. Ani podrobná definice v nejnovější domácí národopisné encyklopedii (Jeřábek 2007, 536-538) nevnáší do těchto otázek zcela jasno, nebot' spolu s přejatým (celoevropským) pojmem maska uvádí alternativní (původní slovanský) název škraboška, přičemž z formulace není zjevné, jaký je mezi nimi vztah, tedy zda je škraboška ekvivalentem, či zvláštním případem masky, nebo jde o specifické termíny pro různé varianty maskování. To je komplikováno také tím, že jako jedna $\mathrm{z}$ forem proměny identity je zde kromě masky a škrabošky netradičně uvedena též figurína.

Podobně i pojem maškara je používán velmi nejednotně - v některých případech se za maškaru považuje celá postava v převlečení (Staňková - Baran 1998, 22) bez ohledu na její projev a funkci, jindy se za stěžejní rys maškary považuje její obecná nevážnost a nevázanost projevující se satirou, žertováním, hlukem, divokým pobíháním a škádlením diváků v protikladu vůči řádu, jenž je reprezentován hierarchicky organizovanými a obřadně se projevujícími koledníky (Stavělová 2008,22 ) bez ohledu na formu jejich převleku. Nejčastěji se však vnímá jako nářeční ekvivalent pojmu maska (Jeřábek 2007, 536).

Je zjevné, že nejednotné a nejednoznačné vymezování těchto pojmů či přímo absence jejich obecně platného pojetí vyplývá ze samotné regionální rozmanitosti maskovaných tradic a jejích lidových (emických) terminologií a interpretací - typickým prŕkladem je třeba odlišování „červených (hezkých)“ a „černých (škaredých)“ maškar na Hlinecku. Pokud však $\mathrm{v}$ odborném terminologickém úzu není shoda v tom, co vlastně lze, nebo naopak nelze pokládat za masku či maškaru ve víceméně přesném, tj. univerzálně použitelném slova smyslu (natož pokud tato otázka není ani položena, problematizována a reflektována), snaha dobrat se obecnějších závěrů o původu, významu a funkcích tradiční lidové masky může být velmi obtížná, ne-li nemožná, zvlášt pokud tyto otázky mají být nahlíženy v širším mezioborovém, multižánrovém či mezikulturním kontextu. Je příznačné, že regionálně vymezené studie či výzkumy zaměřené na konkrétní projevy, formy a žánry maskování převažují nad pokusy o celkové shrnutí a formulaci obecně platných principů. Proto právě tyto ojedinělé pokusy porozumět lidovému maskování v určitém obecném a univerzálním rámci (napr. Zíbrt 1950; Baran 1975; Hrníčko 1977; Tomeš 1979; Frolec 1988; Frolcová 1988; Popelka 1989; Slivka 1990; Staňková - Baran 1998; Holubová 2001; Jeřábek 2007, 536-538; Ebelová 2012, 215-231) jsou tolik cenné. Právě na tyto práce chce následující stat navázat a v konfrontaci $s$ dalšími, zejména zahraničními zdroji je dále rozvinout.

\section{POKUS O VYMEZENÍ A DEFINICI MASKY}

Ve své předchozí práci jsem se o kritický rozbor některých vybraných definic masky již pokusil (Erban 2010: 119-131), vlastní definici či všestranně využitelnému vymezení jsem se však vyhnul argumentem, že pro potřebu obecné, kulturně univerzální teorie masky a fenoménu maskování je spíš než problém, co je vlastně maska, plodnější otázka, co tvoří podstatu masky a od čeho se odvíjí princip maskování. Neboli před otázkou po identitě masky jsem dal přednost otázce po jejím smyslu, podstatě a funkci. Zejména v návaznosti na pojetí britského antropologa A. Davida Napiera (1986) a amerického teatrologa Johna Emigha (1996), ale i celé řady jiných autorů, jsem se pokusil rozvést a obhájit formulaci, že „podstata masky spočívá $v$ tom, že člověku umožňuje složitěji pracovat, zacházet a zahrávat si s identitou" (Erban 2010, 132135). I ta nicméně vědomě rezignovala na exaktnost, výstižnost a všestrannou použitelnost přesně formulované definice, jež byla v některých ohlasech této práce správně postrádána 


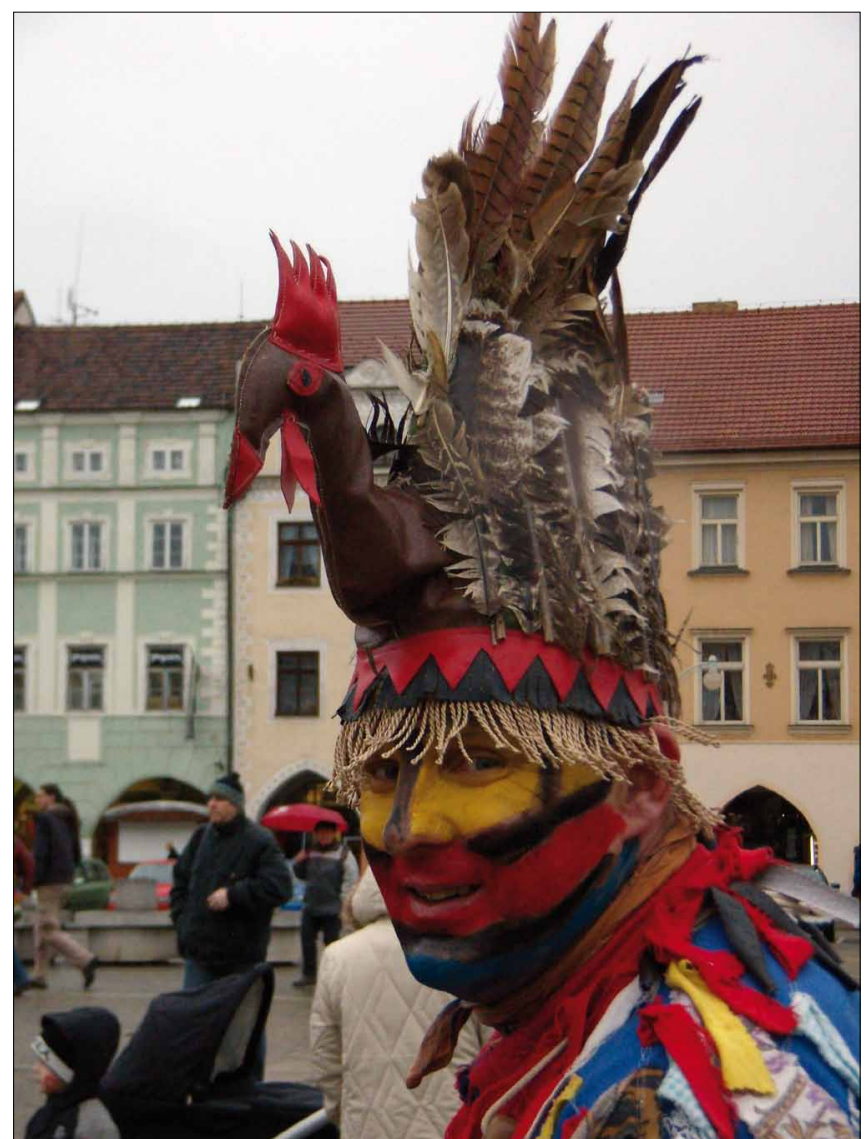

Obr. 1. Maškara „střapatého“ masopustní koledy z Benešova nad Černou v Českých Budějovicích, 2017. (Foto: autor)

(Sítek 2015, 6). O přesnější vymezení užívaných pojmů jsem se sice pokusil na jiném místě (Erban 2011), avšak bez vysvětlujícího, zpřesňujícího komentáře a bez užší vazby na oblast domácí lidové kultury.

Cílem následujících řádek je tedy $\mathrm{v}$ reakci na různé, $\mathrm{v}$ př̀edchozí práci představené a kriticky analyzované definice masky (a v prrímé konfrontaci s nimi) nabídnout co možná nejpřesnější vymezení, které by zahrnovalo všechny funkčně-významové typy masek (tedy masky obřadní, divadelní, zábavní, pohřební i posmrtné, ale i ochranné a statusové) a ověřit tuto definici na př́kladech lidového obřadního maskování. Tento pokus chce překonat určitou izolovanost domácího národopisného studia masek jeho vřazením do mezioborového, multižánrového a mezikulturního kontextu a současně prokázat, že tento širší kontext má v oblasti české lidové kultury velice cenný materiál ke studiu a komparaci. At’ už se navržená definice stane předmětem další revize, kritiky či rozvinutí, nebo bude vyvrácena a zpochybněna, splní svůj pracovní účel. Pokud vyjdeme $\mathrm{z}$ výše nastíněného pojetí masky jako prostředku zacházení s identitou a zvážíme cenné vhledy a poznatky, ale i poučné omyly a opomenutí předchozího studia, lze dospět k následujícímu vymezení:

Maska je tělesný projev, vizuální vzor nebo hmotný předmět, jenž se fyzicky nebo symbolicky vztahuje k osobě nositele a který

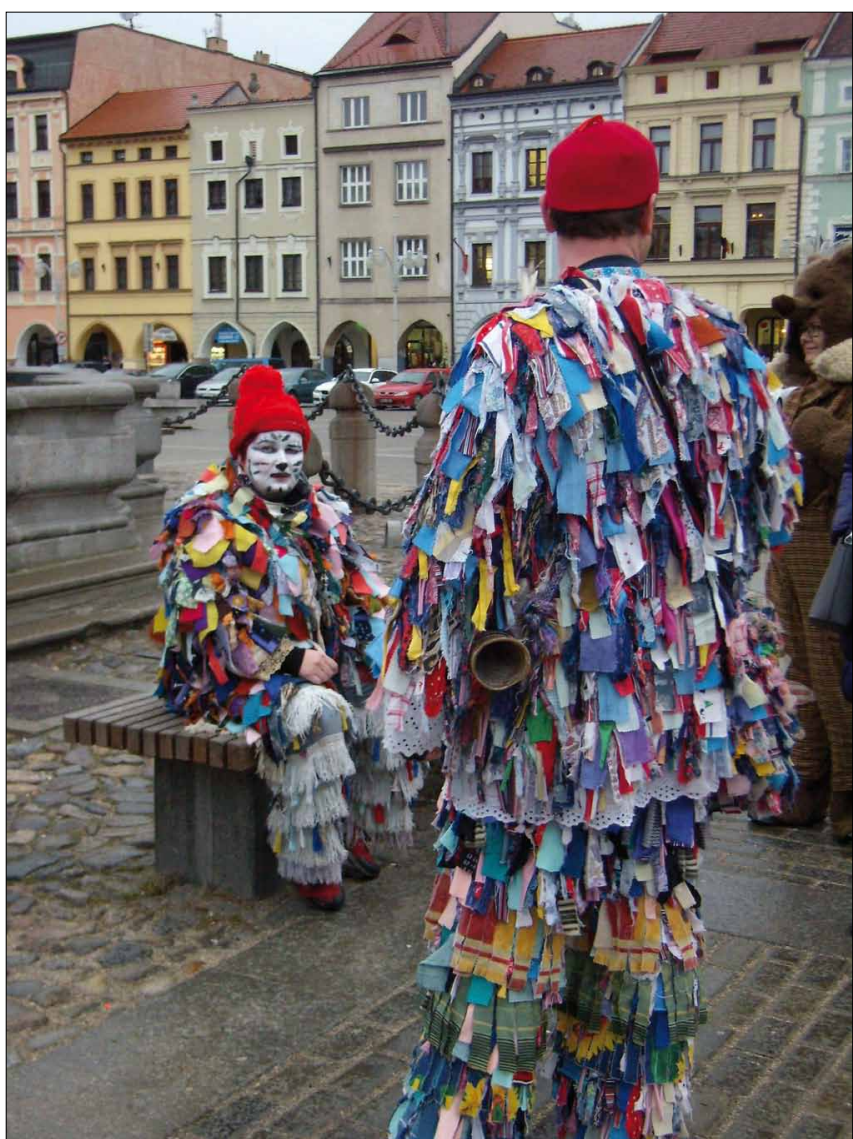

Obr. 2. Maškary Masopustů masopustní koledy z Benešova nad Černou v Českých Budějovicích, 2017. (Foto: autor)

mu při vyhrazených př́ležitostech umožňuje komplexně, flexibilně a k různým účelưm zacházet s identitou sebe sama, masky samotné a/nebo celého obecenstva.

K podnícení případné diskuze je vhodné na některé možné námitky či nejasnosti předem reagovat - vysvětlit a zdůvodnit uvedené znění, a to pomocí vybraných př́kladů obřadního maskování, které dodnes jsou (či do nedávné doby byly) součástí domácích výročních obyčejů.

\section{CO MŮŽE BÝT MASKOU?}

Z první části tvrzení, že maska je tělesný projev, vizuální vzor nebo hmotný předmět, vyplývá, že masku je třeba pojímat jako jev multimediální. Maska může mít trojrozměrnou formu škrabošky nebo kukly (tedy předmětu nasazeného před obličej či na hlavu, jakým je typicky např. dřevěná či kožešinová maska mikulášského čerta či dábla na Valašku), formu plastickou (jako je např. zamoučněná tvář adventních Barborek a vrstva máku či prachového peří nalepeného na medem potřenou tvář u více typů „vousatých“ masek), ale i formu dvourozměrnou, tedy plošnou (jako je např. pomalovaná tvář Masopusta neboli „caprdy“ z oblasti jihočeského Doudlebska nebo začerněná tvář „slaměníkư“ či „slamákư“ na Hlinecku). 


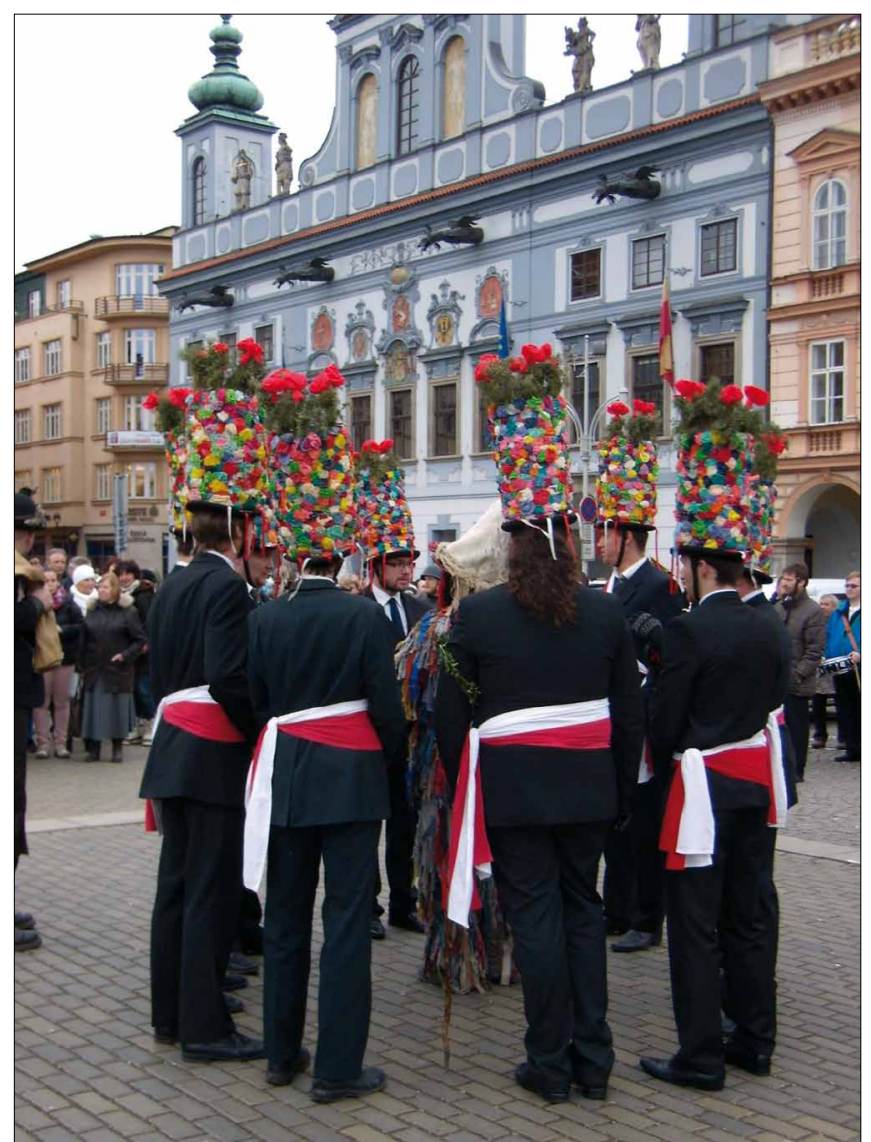

Obr. 3. Mládenecká (růžičková) masopustní koleda z Doudleb v Českých Budějovicích, 2017. (Foto: autor)

Maska však může vzniknout i specifickou úpravou vousů či vlasů (např̀ přehození dlouhých vlasů přes tvář u některých typů Barborek), ale i použitím či zaujetím určité mimiky, gest, postoje, pohybu či hlasového projevu (např. vážnost, důstojnost a obřadnost masky Mikuláše $\mathrm{v}$ protikladu $\mathrm{k}$ divokému pobíhání jeho čertovského doprovodu).

\section{K ČEMU A JAK SE MASKA VZTAHUJE?}

Tvrzení, že maska se vztahuje k osobě svého nositele, reflektuje problém, $\mathrm{k}$ němuž se různí autoři staví odlišně. Někteří autoři (např. Lommel 1972; Sorrel 1973; Napier 1986; Edson 2005) zdůrazňují podstatnou vazbu masky k hlavě či tváři jejího nositele, protože pouze ty jsou jedinečným prostředkem mezilidské identifikace i sebeidentifikace, fungují jako médium projevování emocí (jež maska ve výtvarné stylizaci často napodobuje, přetváří, zdůrazňuje či zveličuje) a jsou v archaickém myšlení vnímány jako centra spirituality a duchovní síly, jež v nich přetrvává i po smrti. Jiní autoři (např. Crumrine 1983; Pernet 2006; Hlaváčová 2007) naopak tuto vazbu rozvolňují a vztahují masku k celému tělu či osobě toho, kdo ji nosí či zaujímá. Např́íklad český režisér, herec a divadelní teoretik Josef František Munclinger ve své příručce pro herce

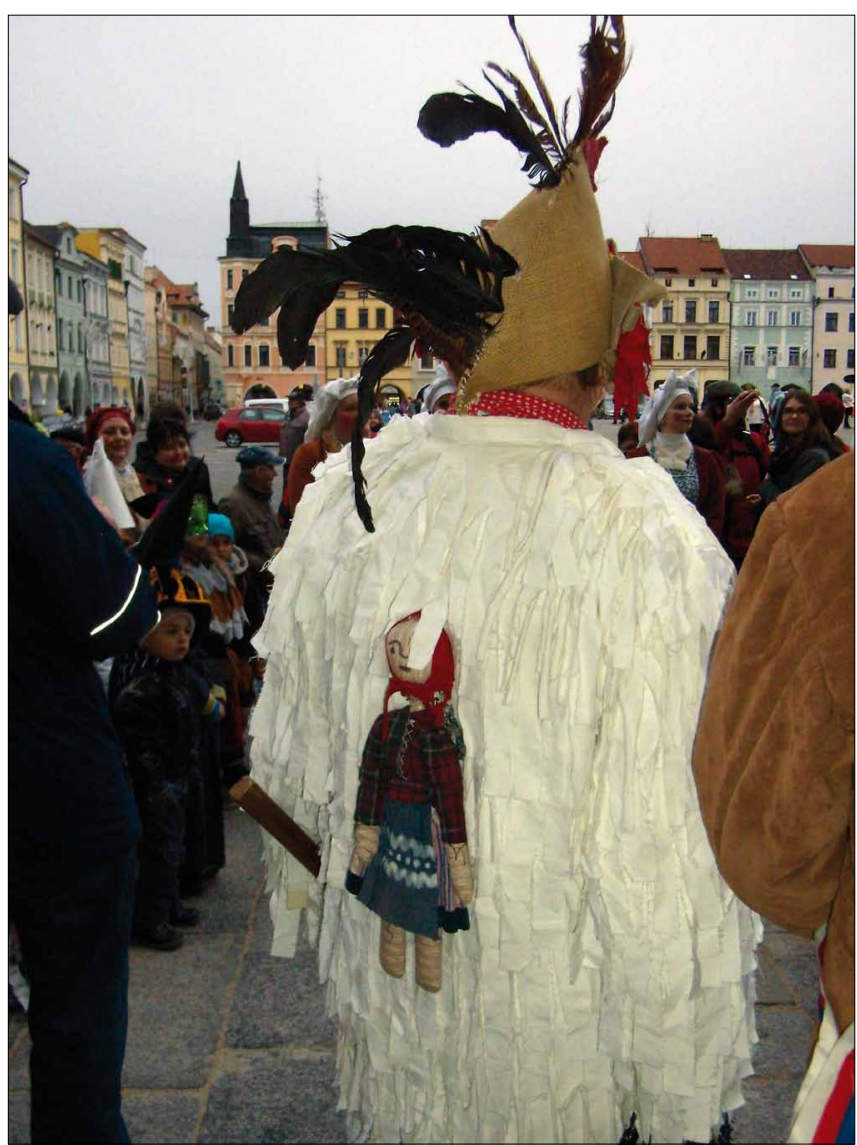

Obr. 4. Maškara „moučného“ masopustní koledy Jihočeského souboru písní a tanců Úsvit v Českých Budějovicích, 2017. (Foto: autor)

tvrdí: „Maskou jest ve hře v̌̌e, co je na herci viditelné. Tedy celé tělo, vše, co herce líčidlem či šatem proměňuje v dramatickou osobu, prostě vše, co herce maskuje (Munclinger 1940, 52). Toto široké teatrologické pojetí, jež za masku považuje „celkový vzhled jevištního hercova převtěleni" (ibid., 104) se podle mého názoru hodí ke studiu projevů maskování v lidové kultuře podstatně lépe než užší definice používané především $\mathrm{v}$ antropologii a muzeologii, které vymezují masku výhradně jejím vztahem ke tváŕi (např. Justoň 1994, 132; Lévi-Strauss 1996; Obuchová 2001, 7; Russell - Etmanskie 2006, 1546; Pernet 2006,6$)$. V tomto smyslu koriguji a nově formuluji také svůj starší pokus o definici (Erban 2011).

Pokud tedy zmíníme různé varianty pojmenování, které se $\mathrm{v}$ češtině používají, pak škraboška a kukla (případně i nářeční „charpa“), jež se bezprostředně vztahují ke tváři či k hlavě, jsou určitými konkrétními typy obecnějšího pojmu maska. Jinou konkrétní variantou masky, která se naopak vztahuje $\mathrm{k}$ celému tělu svého nositele ve smyslu celkového převleku či osoby v přestrojení, vyjadřuje pojem maškara (či „maškarád“). V kontextu domácích výročních obyčejů je specifická pokrývka hlavy (škraboška nebo kukla) či úprava tváře většinou natolik spojena s celkovým kostýmem a jeho atributy, že většinu lidových masek lze specifikovat jako maškary.

Další část definice vymezující, že maska se k osobě nositele 
vztahuje fyzicky nebo symbolicky, chce zdůraznit důležitý a přitom opomíjený fakt, že maska nemusí spočívat na těle, na tvári či na hlavě, ale může se nosit též na ramenou, na zádech, může se držet $\mathrm{v}$ ruce nebo dokonce (jako v prŕípadě posmrtných masek) volně spočívat vedle těla nositele. Pokud se tyto artefakty nějakým způsobem vztahují k osobě svého původce či nositele a vstupují s ním do určitého významového vztahu či napětí, pak (při zachování všech ostatních částí předložené definice) se jedná o masky v pravém slova smyslu. Není třeba zavádět jiné zvláštní pojmy, jako je např. figurína (Jeřábek 2007). Typickým př́kladem je hlava „koníka“ na obruči připevněné $k$ pasu nositele (jenž se tak vizuálně ocitá na koňském hřbetě) nebo „bába“ (připevněná na prsou nositele) nesoucí „dědka“ (tedy skutečného nositele masky) na zádech v nůši. Všechny tyto vtipné, vizuálně působivé a významově plodné varianty jsou založeny právě na onom specifickém napětí mezi maskou a jejím nositelem, které může nastat teprve tehdy, když maska svého nositele nezakrývá, nýbrž se projevuje a působí paralelně s ním. Dochází tak často k efektu zdvojeného vnímání, kdy celek můžeme vnímat paradoxně, jako bud'/a nebo - tedy způsobem, v němž se objekt (maska) může stát subjektem (nositelem masky) a subjekt (nositel masky) pouhým objektem (maskou), přičemž nemusí nastat pouze jedno, nebo druhé, ale též obě možnosti současně (srov. Slivka 1990, 9). Pokud bychom omezili masku jen na ty formy, jež zakrývají tělo, hlavu či tvářr, mnohé z těchto paradoxních a dynamických aspektů maskování bychom zcela ztratili ze zřetele.

$\mathrm{K}$ tomu je třeba dodat, že člověk zachází se svou identitou i jinak než prostřednictvím masky v úzkém slova smyslu ke stylizované sebeprezentaci může sloužit např. i určitá značka (nebo individuálně zvolená SPZ) osobního automobilu, oděvu či styl nebo adresa bydlení. Některé z těchto projevů mohou být natolik symbolicky propracované a vytvářet nebo přetvářet identitu svého původce či majitele tak komplexním způsobem, že se nabízí otázka, zda se i tyto aspekty sebeprezentace nepřibližují určité specifické formě maskování. V každém př́ípadě lze pomocí výše uvedeného vymezení zahrnout do pojmu maska i některé zcela nové varianty a možnosti zahrávání s identitou, které nám poskytuje především virtuální svět sociálních sítí, jako je např. profilový obrázek, pod kterým vstupujeme, často v určité sebestylizaci, do světa virtuální komunikace. Takových netradičních aspektů maskování bude s novými komunikačními technologiemi stále přibývat a lze předpokládat, že už nyní se naše zacházení s identitou přesouvá ve stále větší míre ze světa fyzického do světa mediálního.

\section{KDY SE MASKA POUŽÍVÁ?}

Předložená definice svým důrazem na zvláštní př́ležitosti, během kterých se maska používá, upřesňuje, že situační kontext bývá nějakým způsobem časoprostorově jasně vymezený, formalizovaný, někdy i př́mo ritualizovaný. Díky tomu, že jejich podstata spočívá $\mathrm{v}$ relativitě, ambivalenci a paradoxu, se mas- ky používají při nejrůznějších př́ležitostech tzv. liminálního charakteru, kdy „kontinuita a zmèna, minulost a budoucnost jsou drženy v nesnadné rovnováze, na prahu, uprostřed a mezi starým a novým" (Emigh 1996, 1). Masky jsou ideálním prostředkem $\mathrm{k}$ překračování a propojování jakýchkoli oddělných stádií, úrovní nebo aspektů existence. Maskovaná představení všech výrazových žánrů (at už jde o náboženské, sociální, politické a ekonomické rituály, divadlo, hudbu, tanec, sport, svátky či festivaly), ale do jisté míry to platí i u masek utilitárních a ochranných, které rovněž mohou obsahovat implicitní či explicitní symboliku a stylizaci (srov. Nunley - McCarty 1999, 275-298), se zpravidla vyskytují v situacích nějakého přechodu, proměny a změny stavu. „Jsou provádèné ve vyhrazených časech a na vyhrazených prostorách, jež jsou vyčleněné z období a mist určených $k$ práci, jídlu a spánku. Můžeme je nazvat posvátnými, ovšem při vědomí, že vedle vážnosti a pravidel jsou stejně tak dějištěm hry a experimentováni“ (Turner 1988, 25). Také $\mathrm{v}$ lidové obřadní tradici se používání masek pojilo $\mathrm{s}$ určitými přelomovými fázemi lidského života (svatba, pohřeb) a ročního cyklu, které bylo třeba, mimo jiné pomocí ritualizovaného užití masek, patřičně zvýraznit a vydělit $\mathrm{z}$ každodenního profánního časoprostoru a tak je zdárně překlenout. Proto se s největší koncentrací tradičních forem maskování setkáváme v období kolem zimního slunovratu, Nového roku, na přelomu zimy a jara, dř́ve též v době slunovratu letního.

Aspekt liminality se projevuje také v tom, že pro užívání masek je charakteristické velmi těsné prolínání a propojování základních dualit a protikladů - iluze s realitou, posvátného s profánním, vážnosti (pláče) s veselím (smíchem), rizika, nebezpečí a ohrožení se směšností, obscénností a vulgaritou, ticha a mlčení s křikem a lomozem. Tyto zdánlivě protikladné aspekty se $\mathrm{v}$ představení masek nijak nevylučují, naopak se vzájemně umocňují a často ústí do celkově katarzního, vitalizujícího či apotropaického účinku. Ambivalentní vztah mezi napětím a uvolněním lze považovat za charakteristický a kulturně univerzální rys svátečnosti v jejím původním obsahu (srov. Bachtin 2007, 16-19).

\section{JAK SE MASKA POUŽÍVÁ?}

Kromě situačního kontextu je třeba zvážit také míru komplexnosti maskování. Maska často tíhne k vytváření složitějších, paradoxních nebo ambivalentních symbolických významů, zatímco např. každodenní úprava vlasů či vousů, ženské líčení, brýle, zabarvené oční čočky nebo pokrývky hlavy určené pro určité společenské prŕležitosti mají spíše jen utilitární, estetickou nebo nanejvýše statusovou funkci. Naopak lze za masky považovat rozmanité klobouky, čapky a jiné pokrývky hlavy, které jsou atributem celé řady tradičních postav výročních obyčejů, a to i tehdy, když tvář zůstává odhalena a bez jakéhokoli zdobení. Př́kladem mohou být vysoké klobouky s 365 navrstvenými barevnými růžičkami z krepového papíru a myrtovou či jalovcovou větvičkou s třemi květy navrchu, které nosí tanečníci tzv. růžičkové či mládenecké masopustní koledy na jihočeském Doudlebsku. Tyto atributy mají boha- 
tě propracovaný (byt’ patrně dodatečný) náboženský výklad, přesně naplňují ostatní kritéria našeho vymezení a je lze je tedy považovat za masky v pravém slova smyslu.

Dalším důležitým aspektem masky je její flexibilita, tedy určitá pružnost užití či relativně snadná zaměnitelnost, jež umožňuje a někdy i přímo podněcuje paradoxní a mnohoznačnou dynamiku významů - masku je možné, a to i v rámci jednoho a téhož představení, nasadit nebo sejmout, pozměnit, doplnit nebo pootočit a tím tak měnit její význam a její vztah k osobě nositele nebo k divákům. Některé masky, které jsou mimořádně náročné ke zhotovení nebo které se používají s formálně přesně (až rituálně) stanovenými náležitostmi, nemusí tento aspekt zcela splňovat, nicméně i ty svým projevem vstupují do velice živé, kreativní až destruktivní interakce s jinými maskami či s obecenstvem. Př́kladem mohou být pracně zhotovované masky medvědů ve formě tzv. „hrachovákü“ či „hrachovcư“, „slaměňákü“ či „slaměných“, ale též „(po)hřebenářư“, s nimiž ženy a dívky k zajištění plodnosti tančily, hospodyně si z nich odtrhávaly slámu nebo hrachovinu (které měly velký význam v prosperitní magii), případně po nich házely staré nádobí nebo je máchaly $\mathrm{v}$ potoce $\mathrm{z}$ důvodu obecné očisty od všeho starého, opotřebovaného a nečistého. I takové užití masky lze považovat za projev její flexibility.

Významným aspektem flexibility je také to, že masky mnohdy nevyjadřují pouze jednu jedinou postavu, ale také její vývoj nebo několik postav, at už následně či současně, včetně jejich vztahů a prŕípadných vzájemných transformací. Masky nebývají ve svém původním prostředí chápány mnohdy jako předměty, ale spíše jako prostředky akce, děje, vývoje a proměny. Obecně řečeno, masky je třeba vnímat v jejich spletité a vrstevnaté symbolice, proměnlivé flexibilitě a překvapivé dynamice.

Podle míry flexibility lze uvažovat o pozvolném kontinuu, jehož krajní póly tvoří trojrozměrná maska nasazená na obličej či na hlavu (škraboška či kukla), kterou lze okamžitě a snadno nasadit či sejmout, prŕípadně jakákoli okamžitá úprava zevnějšku (např. přehození dlouhých vlasů přes tvář), na druhé straně pak tetování, skarifikace nebo jiné modifikace těla, které jsou ze své podstaty trvalé a fixní, a proto je nelze za masku považovat. Ačkoli tak někteří autoři činí (např. Edson 2005, 13-16; Ebelová 2013, 38-45), domnívám se spolu s jinými (např. Napier 1986, 3-4; Pernet 2006, 14-15), že zahrnovat do pojmu maskování tyto definitivní úpravy zevnějšku zcela ztrácí výpovědní hodnotu, protože se tak z masky vytrácí její dynamická podstata zakotvená $\mathrm{v}$ paradoxu, mnohoznačnosti a relativitě. Jakmile se jakákoli (nově osvojená) identita stane definitivní, trvalou a neodstranitelnou, přestává být maskou.

\section{K ČEMU A PROČ SE MASKA POUŽÍVÁ?}

Tvrzení, že maska se používá k různým účelům, chce zdůraznit, že funkce masky mohou být velice rozmanité a zdaleka nelze vystačit $s$ nejběžnější typologií masek obřadních, divadelních, posmrtných, statusových či ochranných. Jedna z encyklopedických definic shrnuje tuto paletu užití tak, že „obřadní či formální maska se definuje jako ozdoba hlavy či předmět, který pokrývá tvár za účelem ochrany, rituálu, zábavy, transformace a přetvářky" (Russell - Etmanskie 2006, 1546). V maskách se ztělesňují či personifikují bytosti, věci, jevy a procesy, které je zapotřebí v dané kultuře př́ležitostně nebo periodicky rozehrávat, aktualizovat a realizovat, jako jsou mýtičtí kulturní hrdinové, zviŕata a jejich skutky, předkové, duchové či božstva zodpovědná za přírodní síly a lidské schopnosti, stejně tak mohou být masky vyjádřením lidských povah a společenských rolí a statusů nebo sloužit k zakrytí nebo $\mathrm{k}$ ochraně, zastrašení či jen $\mathrm{k}$ zábavné hře. $\mathrm{V}$ žádné z těchto možných funkcí masky však nelze hledat její podstatu. Neboli masku nedělají maskou její rozmanité účely, nýbrž to, co tyto funkce a účely teprve umožňuje, a tím je její vztah $\mathrm{k}$ identitě. Maska je ze své podstaty prostředek, pomůcka či médium určité práce, zacházení či zahrávání si s identitou.

Zatímco drtivá většina autorů, pokud zmiňují tento zdroj maskování, si všímá pouze skrytí, zdánlivé změny či skutečné transformace identity, která s pomocí masky může nastat (např. Crumrine 1983, 1; Justoň 1994, 132; Staňková - Baran 1998, 22; Obuchová 2001, 7; Pernet 2006, 6; Jeřábek 2007, 536-538; Ebelová 2012, 9), ve skutečnosti skýtá maska daleko více možností v rámci širšího a významově bohatšího rejstř́ku tzv. personifikačních figur (podrobněji Erban 2010, 154-162). Kromě časté možnosti 1) vnitřní změny identity (transu, extáze či posedlosti způsobených maskou, ale také případů, kdy se nositel masky stává nositelem, vykonavatelem či schránkou jejích funkcí a významů, jako je tomu u řady masek zajištujících prosperitu, hojnost a plodnost) může maska obnášet též opačný aspekt 2) udržování, stvrzování či vyjadřování identity (typicky v maskách posmrtných či statusových maskách tajných nebo veřejně fungujících společenství), ale také figuru 3) skrývání či předstírání identity (nejrůznější formy karnevalového, zábavného a dětem určeného maskování) spolu s protikladnou figurou 4) odkrývání či odhalování identity (v evropské lidové kultuře zejména masky Bakuse či Masopusta oslavující univerzální, vše prostupující a věčně trvající tělesnost). Některá maskovaná představení lze umístit výhradně do jedné z těchto čtyř figur, jiná je však třeba chápat $\mathrm{v}$ jejich dynamické oscilaci či kontinuálním přechodu mezi několika figurami. K pohybu identity prostřednictvím masky tedy dochází $\mathrm{v}$ rámci takto vymezeného, ale přitom dostatečně širokého pole základních možností.

\section{JAKÉM KONTEXTU MASKA PU゚SOBÍ?}

Nicméně, s jakou nebo čí identitou maska tímto způsobem zachází? Tvrzení, že maska zachází s identitou svého nositele, sebe samé a/nebo celého obecenstva, vyplývá z všeobecně přijímaného, avšak jen málokdy plně reflektovaného poznatku, že masku nelze chápat jako izolovaný objekt, ale je třeba ji vnímat $\mathrm{v}$ kontextu celého představení (Schechner 2003, 2006). Maska většinou „ožívá“ a nabývá plného smyslu teprve prostřednictvím mimiky, gest, choreografie pohybů celého těla a vztahem ke tváři či osobě nositele, 
ale také úhlem svého natočení směrem $\mathrm{k}$ divákům a celkovou interakcí a komunikací se všemi účastníky představení (srov. např. Pernet 2006, 13). Tento široký kontext je tvořen třemi základními činiteli, a to 1) maskou, 2) nositelem masky a 3) obecenstvem (Crumrine 1983, 3; podobně též Ebelová 2012,9). Teprve $\mathrm{z}$ takto strukturovaného rámce maskovaného představení vyplývají významy, které zůstávají v nejčastěji uváděných definicích masky zcela nepovšimnuté či přehlížené. Pokud se totiž nesoustředíme pouze na samotnou masku, ale přihlédneme též $\mathrm{k}$ jejímu nositeli a přihlížejícímu (či zapojujícímu se) obecenstvu, vidíme, že pohyb identity, ke kterému prostřednictvím masky dochází, se může odehrávat $\mathrm{u}$ všech těchto tří činitelů - bud' pouze u jednoho $\mathrm{z}$ nich, nebo u dvou či dokonce všech současně.

Že maska nemusí zacházet jen s identitou svého nositele, ale také se svojí vlastní identitou, je patrné na př́kladu výše zmíněných masek, které zcela nezakrývají svého nositele, ale vstupují s jeho (a následně i vlastní) identitou do zvláštního významového napětí. Např́íklad součástí masek „židů“ na Českomoravské vysočině a šumavském Podlesí, ale také jihočeských „rybníkářü“ a „caprdy“ (Masopustu či Matky koledy, dříve též „čurky“) jsou figurky panenek připevněné na zádech či na prsou, někdy se zvýrazněnou zástěrkou na klíně. Přesný význam tohoto patrně velmi prastarého motivu, který má určité evropské (Staňková - Baran 1998, 14), ale i mimoevropské obdoby (Werness 2000, 149), je dosti nejasný a v jeho interpretaci se neshodují ani místní účastníci ani etnografové. Přesto je patrné, že zde dochází $\mathrm{k}$ mimořádně silnému významovému napětí $\mathrm{v}$ tom, co maska znamená a jaký je její vztah k osobě nositele. Může jít o symbol a současně magickou rekvizitu plodnosti (pro to by svědčil fakt, že právě tyto masky často útočí na ženy), ale také o ducha či duši, tedy jakési alter ego vyjadřující skrytou čistotu a nevinnost nositele masky, nebo naopak zloducha či démona, na kterého může nositel svádět všechny nezbednosti a špatnosti, které provádí (Staňková - Baran 1998, 26, 85). V každém př́ípadě pomocí tohoto zvláštního atributu si dotyčná maska zahrává jak s identitou sebe samé, tak i svého nositele, už jen tím, že se ukazuje výhradně při pohledu zezadu (nebo při povalování žen do sněhu v obřadní imitaci plodivé kopulace). Obecně lze všechny typy masek, které mění svůj význam už jen choreografií pohybů nebo podle úhlu svého natočení, považovat za masky transformační (tedy masky zacházející s identitou sebe sama).

Že maska a její nositel pracuje též s identitou ostatních nemaskovaných účastníků či diváků, je zřetelné ve všech plodnostních či obecně prosperitních, apotropaických, očistných a regeneračních, ale také sociálně egalitarizujících aspektech tradičních masopustních obchůzek (Popelka 1989, 20). Tak např. dvě maskované postavy „hřebenářư “ na Zlínsku procházely za doprovodu chasy celou vsí a vstupovaly do jednotlivých domácností, kde prováděly ritualizované spílání či hanění - verbálně pranýřovaly skutečné i smyšlené, charakterové i vzhledové špatnosti hospodyň, načež byly ženami zajaty, spoutány a rituálně omývány $\mathrm{v}$ místním potoce. $\mathrm{V}$ jiných regionech byla s "pohřebenáři“ spojena likvidace zničených či opotřebovaných věcí (Šimša 2007, 178-180). Jiným, daleko rozšířenějším a typickým případem je ritualizované souzení a usmrcování obětního zvířete (koně, kozla, berana, kohouta či medvěda) nebo postavy (Matky koledy či Masopusta), prrípadně jejich následné vzkř́íšení, dodnes $\mathrm{v}$ různé podobě prováděné jako součást masopustu v mnoha oblastech Česka (např. Holubová 2001, 22). Ve všech těchto případech na sebe maskovaný obřadník přebírá prohřešky celého společenství nahromaděné za minulý rok a svou obětí očištuje, případně regeneruje a obnovuje životní síly všech ostatních účastníků obřadu. Jedna maškara je tak zástupcem celé komunity a pohyb identity, ke kterému jejím prostřednictvím dochází, je třeba chápat nikoli jen na úrovni individuální, ale také a především úrovni kolektivní.

Vidíme tedy, že v takto široce vymezeném kontextu je třeba interpretovat nejen maskovaná představení jiných kultur, během nichž dochází $\mathrm{k}$ vyloženému transu, posedlosti či extázi, at už nositelů masek nebo ostatních účastníků (Geertz 2000, 132-137) nebo během kterých se používají transformační masky, jež zabudovaným pohyblivým mechanismem důmyslně mění či postupně odkrývají svou identitu (Lévi-Strauss 1996, 37). Též rozmanité aspekty maskování v domácí lidové kultuře, při nichž $\mathrm{k}$ takto razantním posunům identity nedochází nebo které na první pohled nemusejí být zcela patrné, vybízejí k zaujetí této optiky. Maska je zkrátka médiem identity zasahující všechny činitele a aktéry maskovaného představení.

\section{ZÁVĚR}

Je jasné, že řada jevư, v nichž dochází k práci s identitou, běžně označovaných jako maskování, se pohybuje na pomezí výše vymezeného pojetí a teprve po zvážení situačního kontextu, míry komplexnosti a flexibility můžeme vážit, je-li takové označení adekvátní, pouze odvozené či metaforické, nebo př́mo zavádějící a nesprávné. Masky díky svému zakotvení v relativitě, paradoxu a ambivalenci nemohou mít zcela pevný a jasně definovatelný status. Předložená definice nabízí pouze určité faktory, které je vzít v úvahu, neumožňuje však stanovit jakékoli jasné hranice a pevné kategorie. Ve studiích zaměřených na určitou konkrétní oblast je třeba přihlížet k místním terminologickým zvláštnostem a specifikům (v některých regionech Česka např. používají účastníci pojem maškara, „maškarování“ či maškaráda k pojmenování celého průvodu masek) a případně jim dávat přednost před odborným, obecně zavedeným jazykovým územ. Avšak ve studiích, které jsou zaměřeny komparativně nebo které se snaží o postižení obecného charakteru maskování $\mathrm{v}$ delším časovém či širším prostorovém záběru (tím spíše v mezioborovém, multižánrovém nebo mezikulturním kontextu), je vhodné vycházet $\mathrm{z}$ určité ustálené a obecně akceptované terminologie. Tato stat se pokouší jedno z možných vymezení nabídnout a teprve její prrípadné využití v terénu a na jednotlivých specifických případech může potvrdit, upřesnit nebo vyvrátit její platnost a adekvátnost. 


\section{LITERATURA}

Bachtin, Michail Michajlovič (2007): François Rabelais a lidová kultura středověku a renesance. Praha: Argo.

Baran, Ludvík (1975): Masky, démoni, šaškové. Umění a řemesla, 1, 42-46. Caillois, Roger (1968): Zobecněná estetika. Praha: Odeon.

Caillois, Roger (1998): Hry a lidé. Maska a závrat. Praha: Nakladatelství Studia Ypsilon.

Crumrine, Ross N. (1983): Masks, Participants, and Audience. In: Crumrine, Ross N. - Halpin, Marjorie, eds., The Power of Symbols. Masks and Masquerade in the America. Vancouver: Univeristy of British Columbia Press, 1-11.

Ebelová, Kateřina (2012): Maska v proměnách času a kultur. Praha: Grada.

Edson, Gary (2005): Masks and Masking. Faces of Tradition and Belief Worldwide. Jefferson: McFarland.

Emigh, John (1996): Masked Performance. The Play of Self and Other in Ritual and Theatre. Philadelphia: University of Pennsylvania Press.

Erban, Vít (2010): Maska a tvár. Hra s identitou v mezikulturních proměnách. Praha: Malá Skála.

Erban, Vít (2011): Maska (maškara; maskaron; maskot; persona). In: Malina, Jaroslav, et al., eds., Encyklopedie antropologie. Brno: Masarykova univerzita (online). http://is.muni.cz/do/sci/UAntrBiol/el/encyklopedie/ index.html.

Frolcová, Věra (1988): Pokus o klasifikaci folklóru obřadních obchůzek. In: Frolec, Václav, ed., Obřadní obchůzky. Uherské Hradiště: Slovácké muzeum - Ústav lidového umění, 59-76.

Frolec, Václav (1988): Obřadní obchůzky „Svatých noci“': k jejich genezi a významu. In: Frolec, Václav, ed., Obřadní obchůzky, Uherské Hradiště: Slovácké muzeum - Ústav lidového umění, 13-36.

Geertz, Clifford (2000). Interpretace kultur. Vybrané eseje. Praha: Sociologické nakladatelství.

Holubová, Markéta (2001): Masopustní maska v českých zemích. In: Obuchová, Lubica, ed., Maska, kostým a lidové divadlo. Praha: Česká orientalistická společnost / Dar Ibn Rushd, 13-23.

Hlaváčová, Anna A. (2007): Homo ludens africanus, alebo, Pohlady na predstavenia masiek západnej Afriky. Bratislava: Kalligram.

Hrníčko, Václav (1977): Masopustní maškarní obchůzky v českých zemích: jejich vývoj a proměny. Muzeum a současnost, řada společenskovědní, 109-123.

Hrníčko, Václav (1988): Aktualizace a funkční posuny v masopustních obyčejích (na příkladu vybraných masek z Hlinecka). In: Frolec, Václav, ed., Obřadní obchůzky. Uherské Hradiště: Slovácké muzeum - Ústav lidového umění, 139-155.

Jeřábek, Richard (2007): Maska, škraboška a figurína. In: Brouček Stanislav - Jeřábek, Richard, eds., Lidová kultura. Národopisná encyklopedie Čech, Moravy a Slezska, 2. svazek, věcná část A-N. Praha: Mladá fronta, 536-538.

Justoň, Zdeněk (1993): Maska. In: Holý, Ladislav - Soukup, Václav - Vodáková, Alena, eds., Sociální a kulturní antropologie. Praha: Sociologické nakladatelství / Sociologický ústav AV ČR, 132-134.

Komárek, Stanislav (2016): Mimikry a př́buzné jevy. Dějiny poznávání a výkladu vnějšiho vzhledu živých organismů. Praha: Academia.

Komárek, Stanislav (2008): Př́roda a kultura. Svět jevů a svět interpretací. Praha: Academia.

Kratochvíl, Matěj - Tyllner, Lubomír (2007): Masopustní koleda na Doudlebsku. Dobrkovská Lhota. Praha: Etnologický ústav AV ČR.

Lévi-Strauss, Claude (1996): Cesta masek. Liberec / Praha: Dauphin.

Lommel, Andreas (1972): Masks. Their Meaning and Function. London: Paul Elek.

Mack, John, ed. (1994): Masks. The Art of Expression. London: British Museum Press.
Munclinger, Josef František (1940): Hercova tvář a maska. Umění masky. Praha: Českomoravský Kompas.

Napier, David A. (1986): Masks, Transformation, and Paradox. Berkeley: University of California Press.

Nunley, John W. - McCarty, Cara, eds. (1999): Masks. Faces of Culture. New York: Harry N. Abrams.

Obuchová, Lubica, ed. (2001): Maska, kostým a lidové divadlo. Praha: Česká orientalistická společnost / Dar Ibn Rushd.

Pernet, Henry (2006): Ritual Masks. Deceptions and Revelations. Eugene: Wipf \& Stock.

Popelka, Pavel (1989): Masky v masopustních obyčejích. Malovaný kraj, 25(1), 20-21.

Portmann, Adolf (1997a): Nové cesty biologie I. In: Scientia \& Philosophia: 7, Praha: Hrnčířství a nakladatelství Michal Jůza \& Eva Jůzová, 49-161.

Portmann, Adolf (1997b): Nové cesty biologie II. In: Scientia \& Philosophia: 8, Praha: Hrnčířství a nakladatelství Michal Jůza \& Eva Jůzová, 3-112.

Russel, Karen Hodge - Etmanskie, Jenny (2006): Mask, ceremonial. In: Birx James H., ed., Encyclopedia of Anthropology 1-5. Thousand Oaks: Sage Publications, 1546-1549.

Schechner, Richard (2003): Performance Theory. London: Routledge.

Schechner, Richard (2006): Performance Studies. An Introduction. London: Routledge.

Sítek, Martin (2015): Symbolika a funkce masek ve vybraných lidových obyčejích výročního cyklu na Moravě. Brno: Masarykova univerzita, Filozofická fakulta - Ústav evropské etnologie (diplomová práce).

Slivka, Martin (1990): Ludové masky. Bratislava: Tatran.

Sorrel, Walter (1973): The Other Face. The Mask in the Arts. London: Thames and Hudson.

Staňková, Jitka - Baran, Ludvík (1998): Masky, démoni, šaškové. Pardubice: Theo.

Stavělová, Daniela (2008): Červená rǔžičko, proč se nerozvijí̌s. Doudlebská masopustní koleda: tanec, identita, status a integrace. Praha: Etnologický ústav AV ČR.

Šimša, Martin (2007): Masopustní obchůzka „hřebenářưu - nové aspekty jejího výkladu. Národopisná revue, 17(44), 178-181.

Tomeš, Josef (1979): České a slovenské masopustní obyčeje a jejich mezinárodní obměny. In: Frolec, Václav - Tomeš, Josef, eds., Masopustní tradice, Brno: Blok, 37-49.

Turner, Victor (1988): The Anthropology of Performance. New York: PAJ Publications.

Vojancová, Ilona (2014): Masopust na Hlinecku. Územní památková správa na Sychrově: Národní památkový ústav.

Werness, Hope B. (2000): The Continuum Encyclopedia of Native Art. Worldview, Symbolism, and Culture in Africa, Oceania, and North America. New York / London: Continuum.

Zíbrt, Čeněk (1950): Veselé chvíle v životě lidu českého. Praha: Vyšehrad.

\section{AUTOR}

Vít Erban $\left({ }^{\star} 1974\right)$, kulturolog, prozaik a esejista. Vystudoval dramaturgii a scenáristiku na Filmové fakultě AMU a kulturologii na Filozofické fakultě UK v Praze, kde absolvoval též postgraduální studium. Od roku 2003 pracuje jako odborný asistent na Teologické fakultě a Filozofické fakultě JU v Českých Budějovicích. Věnuje se především symbolické antropologii a vybraným tématům $\mathrm{z}$ antropologie náboženství a antropologie umění, zvláštní pozornost věnoval vztahu kultury a př́rody $\mathrm{v}$ díle amerického básníka, esejisty a orientalisty Garyho Snydera. Ve své literární tvorbě tíhne především $\mathrm{k}$ minimalistickým literárním útvarům a formám na pomezí poezie a prózy. 